\title{
Delimitation of the Perimeters of Protection of Groundwater Catchments of the Berrechid Aquifer (Morocco) through Hydrogeological Modeling
}

\author{
Karima El Bouqdaoui', Mostafa Aachib ${ }^{2}$ \\ ${ }^{1}$ Environment Sciences Laboratory, Faculty of Sciences, Aïn Chock University Hassan II, Casablanca, Morocco \\ ${ }^{2}$ Department of Hydraulic, Hassania School of Publics Works, Casablanca, Morocco \\ Email: elbouqdaouik@gmail.com,maachib@hotmail.com
}

How to cite this paper: El Bouqdaoui, K. and Aachib, M. (2018) Delimitation of the Perimeters of Protection of Groundwater Catchments of the Berrechid Aquifer (Morocco) through Hydrogeological Modeling. Journal of Geoscience and Environment Protection, 6, 101-112.

https://doi.org/10.4236/gep.2018.67008

Received: April 27, 2018

Accepted: July 24, 2018

Published: July 27, 2018

Copyright $\odot 2018$ by authors and Scientific Research Publishing Inc. This work is licensed under the Creative Commons Attribution International License (CC BY 4.0).

http://creativecommons.org/licenses/by/4.0/

cc) (i) Open Access

\begin{abstract}
Over the last two decades, repeated dry periods across the country have clearly highlighted the weaknesses in the balance of needs and surface water resources. The latter are increasingly failing due to the large inter-annual rainfall variability and high exposure to evaporation. Because of their high inertial capacity, groundwater is less affected by interannual fluctuations and compensates for the irregularity of surface water availability. However, in addition to being overexploited, groundwater can be exposed to various types of pollution that can alter their quality, sometimes irreparably. The issue of delimiting the protection perimeters around catchments implies a local development policy that is coherent from the point of view of water management and spatial planning. The present work contributes to the delimitation of the perimeters of protection of groundwater catchments of the Berrechid aquifer. Thanks to the "particle tracking" method through the use of models MODPATH and MODFLOW interfaced to GMS 4.0 (Groundwater Modeling System Version 4.0), we delimited the closed protection perimeters, using the numerical MODPATH model, by drawing the 50-day isochrones. Within these perimeters, any bacteriological or chemical action is prohibited. We delimited also the distant protection perimeters (infinite transfer time) that serve as an extension to the closed protection perimeters (transfer time of 50 days). Feeding areas have been introduced to protect groundwater from substances with insufficient degradation and natural retention. The results obtained show that these wells (catchments (P1 to P9) intended for drinking water supply in the Berrechid region) could be contaminated if the part of the aquifer to the south, upstream of these wells, is polluted by persistent chemical substances. The agricultural activities must be controlled and regulated by the State au-
\end{abstract}


thorities in order to avoid any risk of contamination of the new boreholes by phytosanitary products since Berrechid region is an agricultural zone.

\section{Keywords}

Groundwater, Perimeters of Protection, Modeling, Drinking Water, MODPATH, MODFLOW, Berrechid

\section{Introduction}

The Berrechid aquifer is relatively small in size compared to the water needs in the region (drinking and industrial water supply, irrigation, etc.). This should, a priori, encourage a particularly vigilant approach in its quantitative and qualitative management.

Adverse weather conditions and intensive groundwater exploitation have led to alarming decreases in levels in most of the semi-arid to arid zones of Morocco [1]. Per capita water reserves, which are already approaching the stress threshold of $1000 \mathrm{~m}^{3} /$ inhabitant/year, would be around $500 \mathrm{~m}^{3} /$ inhabitant/year in 2020 [2]. Several studies carried out in this respect have repeatedly highlighted the piezometric deficit, over-exploitation [3], quality degradation (many wells whose nitrate concentration was more than $50 \mathrm{mg} / \mathrm{L} \mathrm{[4]} \mathrm{[5]} \mathrm{[6])} \mathrm{and} \mathrm{inadequate} \mathrm{man-}$ agement of water resources.

Morocco's water resources suffer from a strong irregularity in space and time. The use of the mobilized resource is $91 \%$ to $94 \%$ for agriculture and only $6 \%$ to $9 \%$ for the supply of drinking water and industrial water. Long periods of drought combined with increased water needs are creating imbalances in quantity and quality in most aquifers in Morocco [7].

The MODFLOW modeling provided a better understanding of the hydrodynamic functioning of the Berrechid aquifer. During this modeling, the balance sheet turned out to be negative over the simulated period; this is due to increasing exploitation of groundwater, combined with dry climatic conditions [5] [8].

In order to prevent possible contamination of the new boreholes, and to guarantee at long-term good water production, it is important to set up protection perimeters around the boreholes. Therefore, perimeters of protection are an essential component of the groundwater management in the perspective of the sustainable development of Berrechid aquifer.

The protection of groundwater catchments (wells, boreholes, springs) against surface pollution is therefore becoming more and more essential. It consists in setting up, around these catchments, protection perimeters within which certain activities are prohibited or regulated.

\section{The Study Area}

The Berrechid plain, with a total area of $1600 \mathrm{~km}^{2}$, is located south of Casablanca 
(Figure 1). It is in the form of a bowl with a large radius of curvature of elliptical shape whose major axis is oriented substantially South West-North East, a length of about $60 \mathrm{~km}$. It is limited to the South-East by the Settat Plateau, to the North-East by the Mellah Wadi Valley, to the South-West by the Souk-Jemaa Peninsula, and to the North-West by the Dune Sahel parallel to the shore

The Berrechid Plain fits into the category of arid to semi-arid regions. This character is however mitigated by the proximity of the ocean. The annual total rainfall is low and the number of rainy days is low. The dry period is spread over a six-month period, from May to October [10] [11].

The hydraulic network of the plain of Berrechid is very little developed, although many small wadis drain the plateau of Ben Ahmed-Settat and converge towards the center of the plain. These wadis are, from north-east to south-west, Asseïla, Aïda, El Ahmeur, Mazere and Tamdrost (Figure 1).

Among the studies that have focused on the Berrechid aquifer are Bolelli and Lesguisé ([12] [13]), Moullard and Hazan ([14]), Moniton and Nerat De Lesguisé ([15]), Hazan and Ferre ([16]), DGH ([10]), El Mansouri ([17] [18]), Kholtei ([4]), El Bouqdaoui ([5]) and El Bouqdaoui et al. ([6] [8]).

\section{Material and Method}

The following sections describe the material and the methodology used in this study.

\subsection{Material}

The establishment of the hydrogeological model of Berrechid aquifer required a database. The data used result from geological and hydrogeological works carried out on Berrechid aquifer ([4] [10] [19]). Hydrodynamic parameters such as hydraulic conductivity (permeability), coefficient of storing, porosity and Piezometric data have been used in the implementation of this model [8].

The delimitation of the perimeters of protection is based on the prohibition of any action likely to pollute the water table over a distance such that the transit time of the pollutants is sufficient enough for them to be degraded before reaching the catchment.

The protection perimeters of groundwater catchments are of three types: the immediate protection perimeter, the closed protection perimeter and the distant protection perimeter (Figure 2) [20].

Groundwater flow of the Berrechid aquifer modeling and protection perimeters determination were carried out using Visual ModFlow provided by GMS version 4.0 [21]. This software integrates three codes:

- ModFlow for the groundwater flow simulation;

- ModPath simulates the pathways of water particles;

- MT3D for mass transfer simulation.

The mathematical digital models of hydrodynamic flow are based on finite 


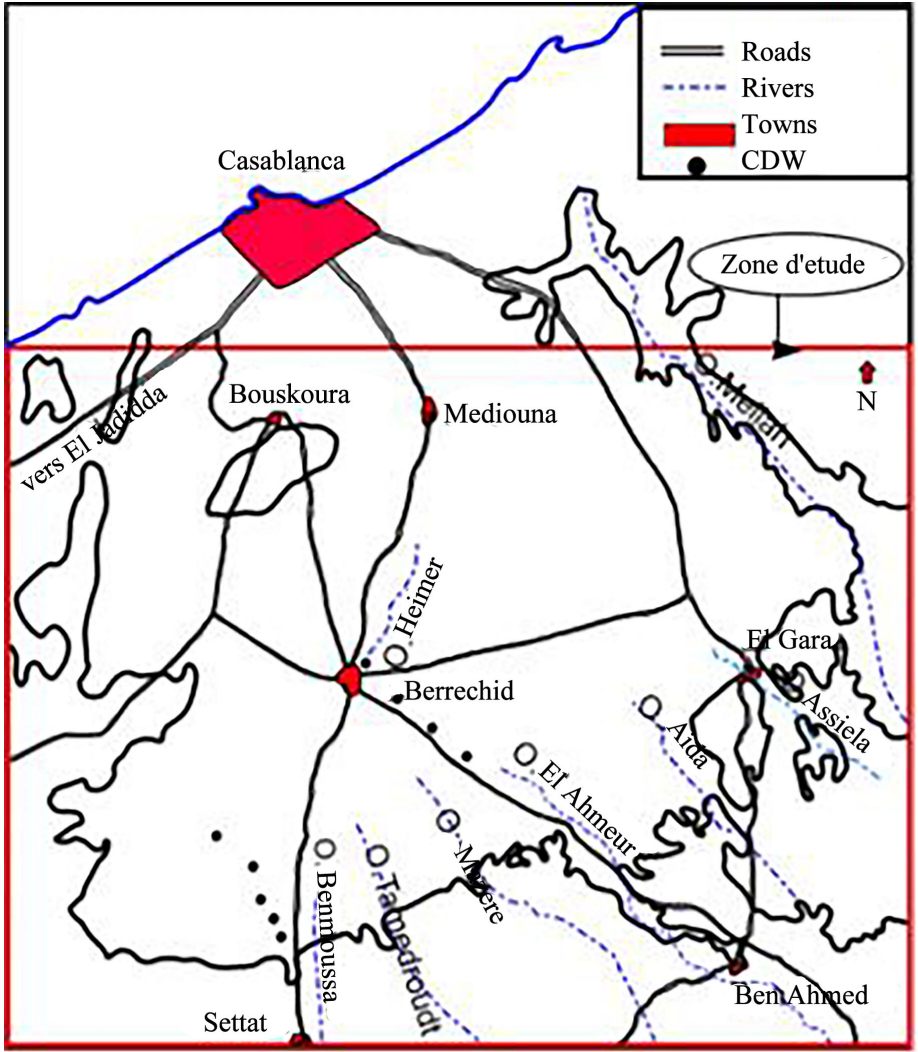

Figure 1. Location of the Berrechid plain [8] [9]. (CDW: Catchments of the drinking water).

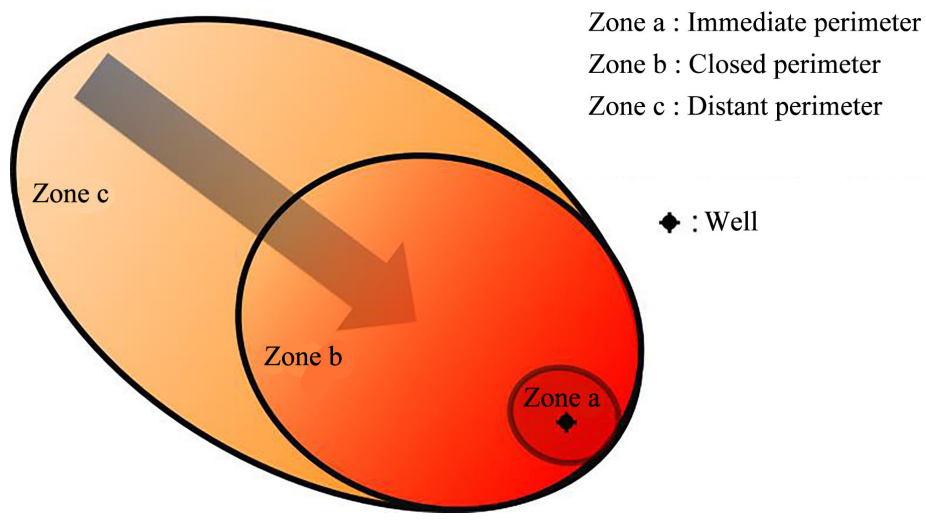

Figure 2. Presentation of perimeters of protection around a pumping well.

differences or finite elements. ModFlow allows to approximate flow equation solution through finite-difference method.

\subsection{Methodological Approach}

The selection of a protection perimeter analysis method is based on the general hydrogeological characteristics of the site, the phenomena to be studied, the results to be achieved and the degree of accuracy sought [22]. 
In general, the more the method allows the integration of the geological, hydrological and hydrogeological characteristics of the environment, the more precise it is [23].

The model is a numerical schematization of the hydrogeological system. It allows you to go from a natural complex system, the ground, to a whole model digital, the model development requires several steps, such as the determination of objectives to be achieved, the choice of the software used, the design of conceptual model [8], model calibration and finally the realization of predictive simulations (Figure 3).

The protection perimeters (closed and distant) can be delimited numerically using the MODPATH model using the so-called "particle tracking" tracing technique [6] from the piezometric distribution calculated by the MODFLOW flow model. This technique consists in following the advective trajectory of virtual particles placed in a flow field, thus making it possible to determine the flow lines and the associated transfer times. The path of the particles can be tracked in the direction of the flow (forward tracking) or "backward tracking". It is this last technique that we used after injection of virtual tracing particles in groundwater catchments.

\section{Results and Discussions}

The trajectories of the tracer particles are made using the model MODPATH integrated in GMS. These trajectories are determined mesh by mesh, by integrating in each mesh the real flow velocities calculated from the generalized Darcy's law by using the spatial distribution of the pizometric levels simulated by MODFLOW.

The hydraulic characteristics, namely the hydraulic conductivity and the storage coefficient of the aquifer used, are those obtained by calibration of the numerical model [8].

Figure 4 shows the distribution of the hydraulic conductivities restored by the calibration of the model showed five zones of permeabilities, with a maximum of $7.5 \times 10^{-2} \mathrm{~m} / \mathrm{s}$ and a minimum of $10^{-6} \mathrm{~m} / \mathrm{s}$, which respects the lithology of the corresponding formations [5].

The values of the storage coefficient from transient calibration vary between $5.0 \times 10^{-4}$ and 0.2 . These variations are due mainly to lateral facies changes in the aquifer and the type of flow of the aquifer.

Figure 5 shows the distribution of values of the storage coefficient obtained after calibration of the model under transient conditions [5] [8].

The simulations relate to the main groundwater catchments (P1 to P9) intended for drinking water supply in the Berrechid region (Figure 6).

\subsection{Closed Protection Perimeters}

In this section, we delimit the closed protection perimeters, using the numerical MODPATH model, by drawing the 50-day isochrones. 


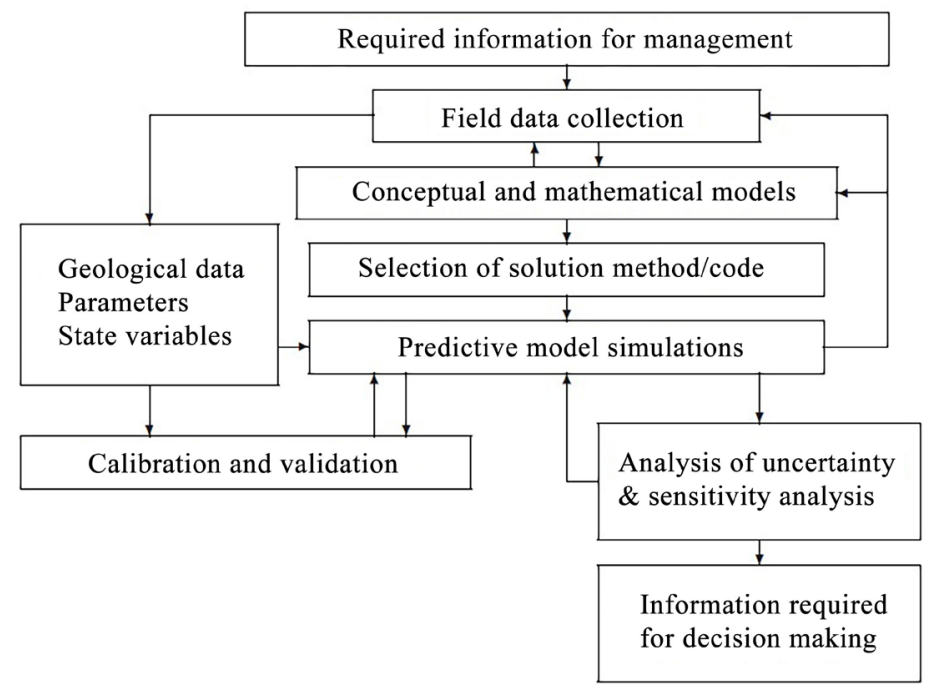

Figure 3. The modeling process [24].

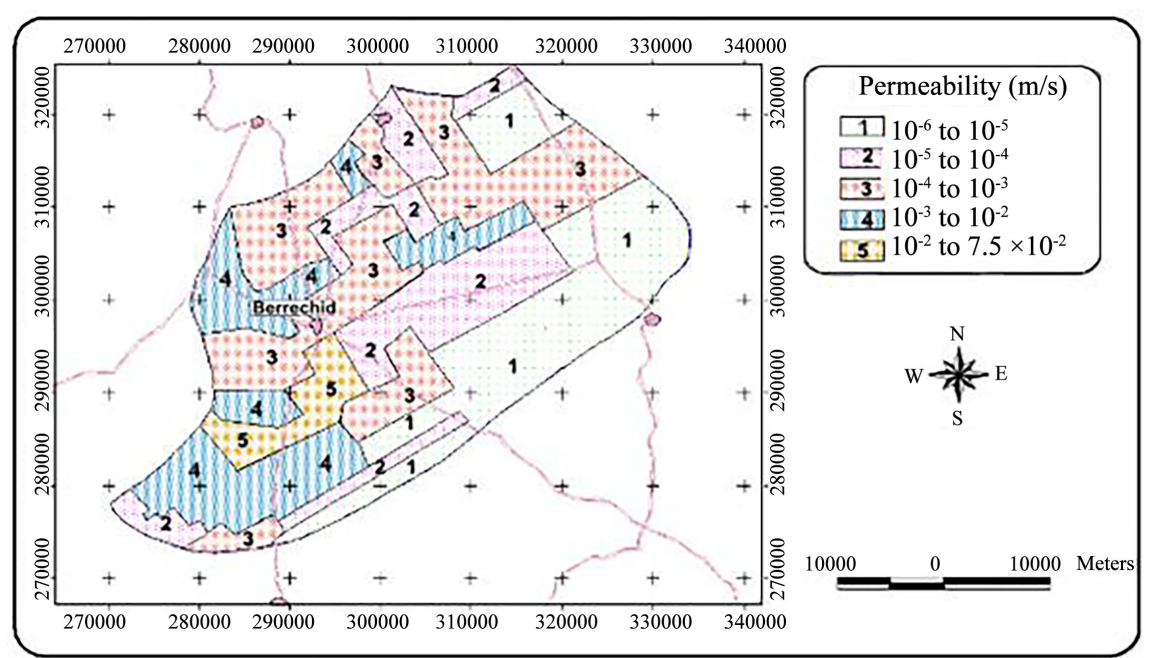

Figure 4. Distribution of the permeabilities resulting from steady-state calibration.

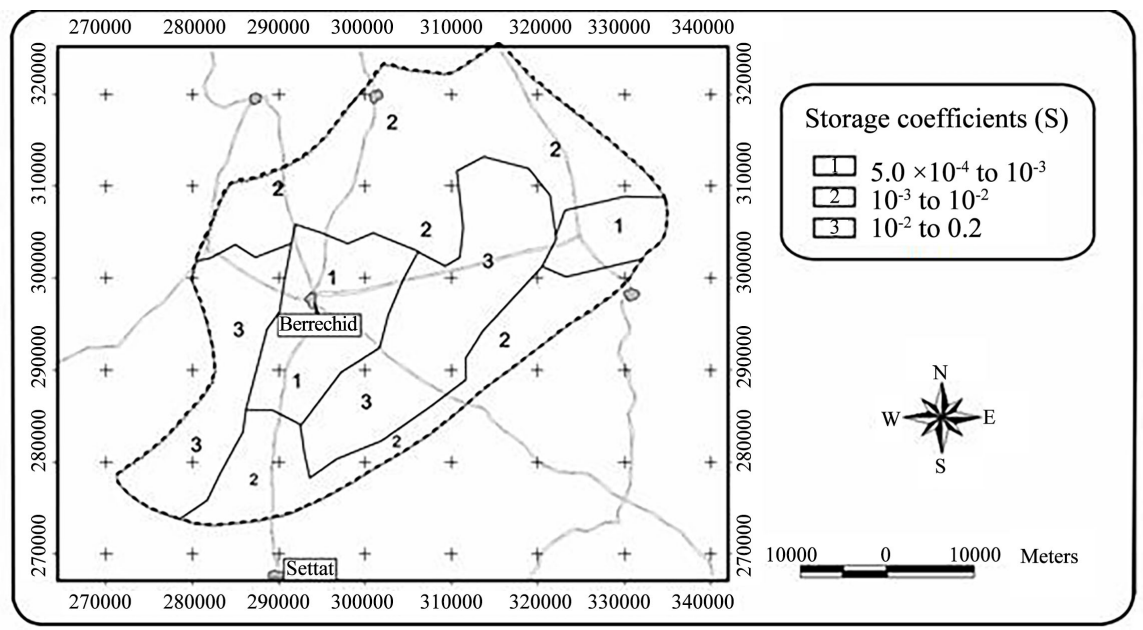

Figure 5. Distribution of storage coefficients from transient calibration. 


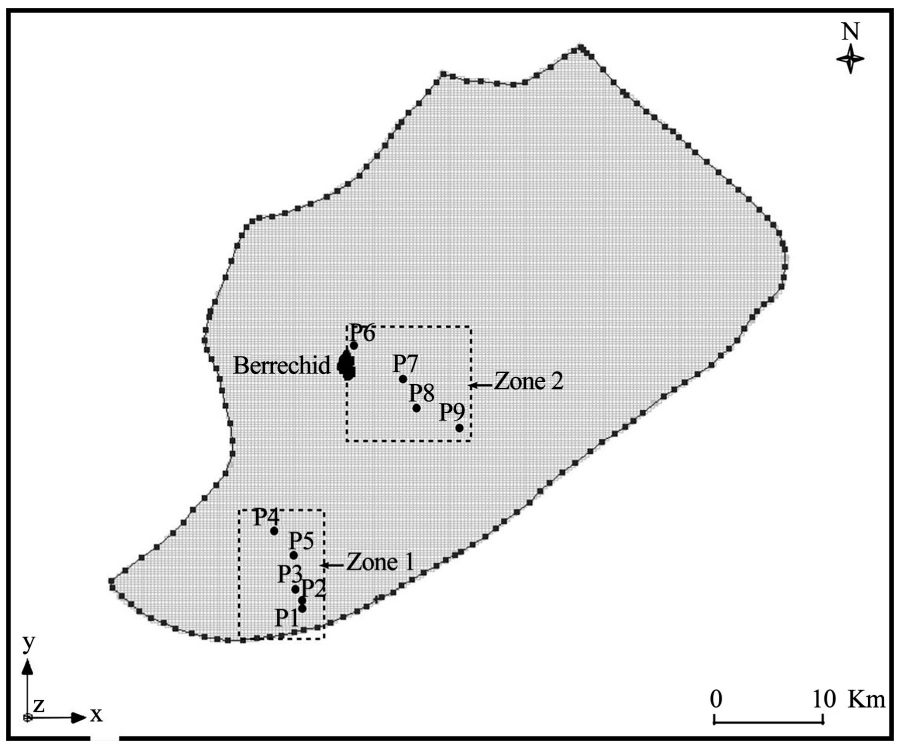

Figure 6. Major drinking water supplies the Berrechid nappe [10] [19].

Figure 7 and Figure 8 show, respectively, the closed protective perimeters retracted from the drinking water supply wells located in zones 1 and 2 of Figure 6.

These perimeters, of elliptical shape, extend over variable surfaces. Within these perimeters, any bacteriological or chemical action is prohibited. The delimitation of protection perimeters has important consequences for the community, both in terms of health (protection and sustainability of the quality of the water produced) and economic (expropriations, costs of easements and protective works, constraints on land occupation). It is therefore necessary to have the possibility of optimizing the dimensions of the protection zones to minimize the constraints of the servitudes prevailing.

\subsection{The Distant Protection Perimeter}

Feeding areas have been introduced to protect groundwater from substances with insufficient degradation and natural retention. Indeed, the concepts of groundwater protection based on transit times, do not always prevent the arrival of these substances to capture. On the other hand, in the field of agriculture, good farming practices are not generally enough to sufficiently reduce the concentration of agricultural pollutants in groundwater. The purpose of these areas is therefore to define the most vulnerable sectors, with a view to applying protection actions as far as possible. These can be proposed for sanitation in already polluted waters, but also to prevent future contaminations. They are not determined on the basis of the flow of pollutant at a given moment, but on the circulation of water. These condition the transport of the majority of pollutants and have a lasting character over time, which makes it possible to propose long-term actions.

The MODPATH model also allows us to determine the feeding areas of water 


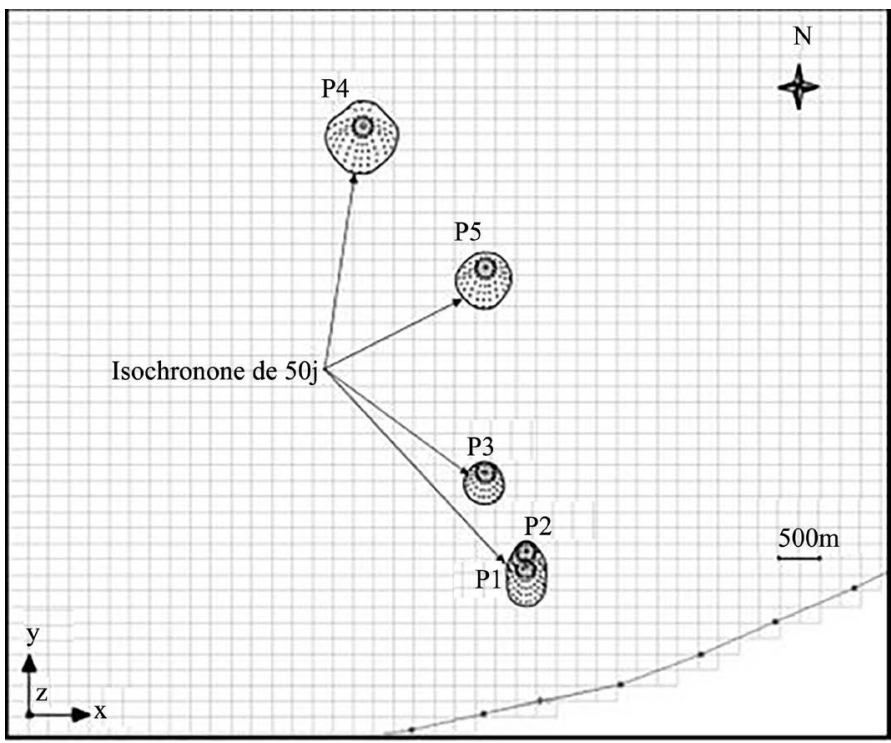

Figure 7. The closed protective perimeters of supply wells: 1951/27 (P1), 1950/27 (P2), 3061/27 (P3), 2024/27 (P4) and 1199/27 (P5).

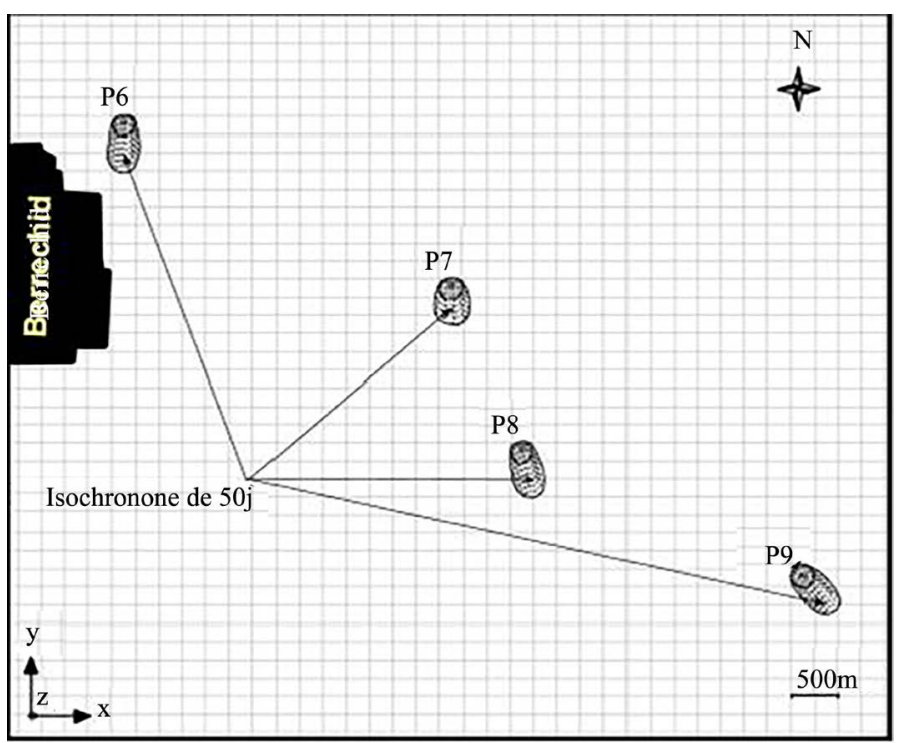

Figure 8 . The closed protective perimeters of supply wells: $876 / 28$ (P6), 3011/28 (P7), 1431/28 (P8) and 2149/28 (P9).

catchments (Figure 9). These areas correspond to the distant protection perimeters (infinite transfer time) that serve as an extension to the closed protection perimeters (transfer time of 50 days).

The area to be protected as a priority against pollution due to human activity is usually located upstream of the catchment and within a so-called capture (or catchment) area.

Figure 9 and Figure 10 show that these wells could be contaminated if the part of the southern water table, upstream of these wells, is polluted by persistent chemical substances. Thus, it would be useful to set up a pollution alert system 
in these vulnerable zones, the function of which would be to detect a contaminant at a sufficiently large distance from a well to allow an effective intervention. In practice, this warning network should consist of control piezometers where the quality of the water would be checked periodically.

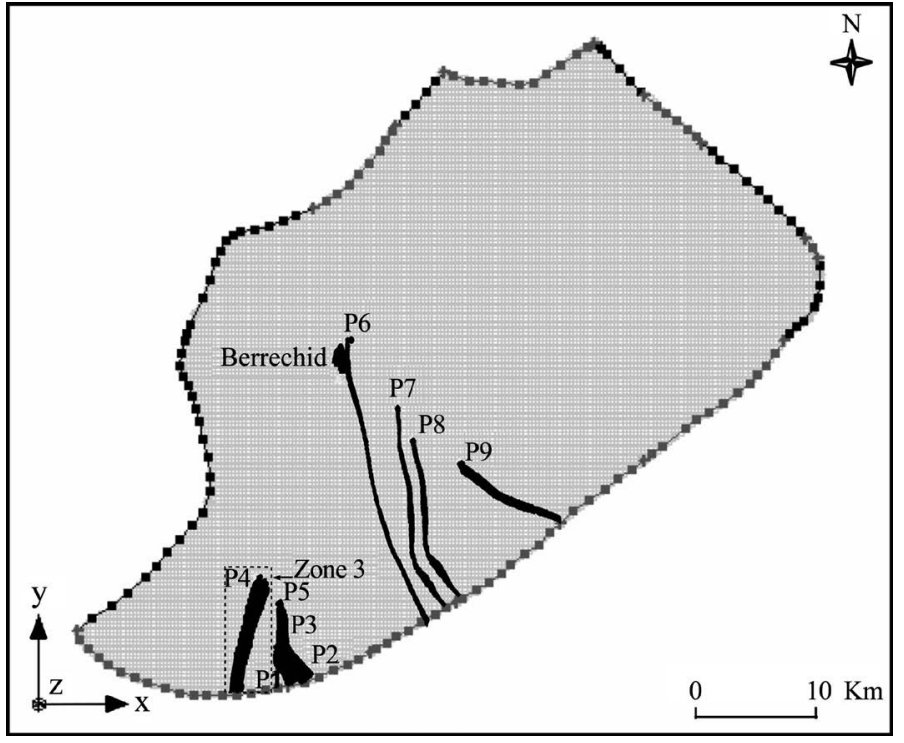

Figure 9. Path of water virtual particles captured by the boreholes and delimiting the protection zones.

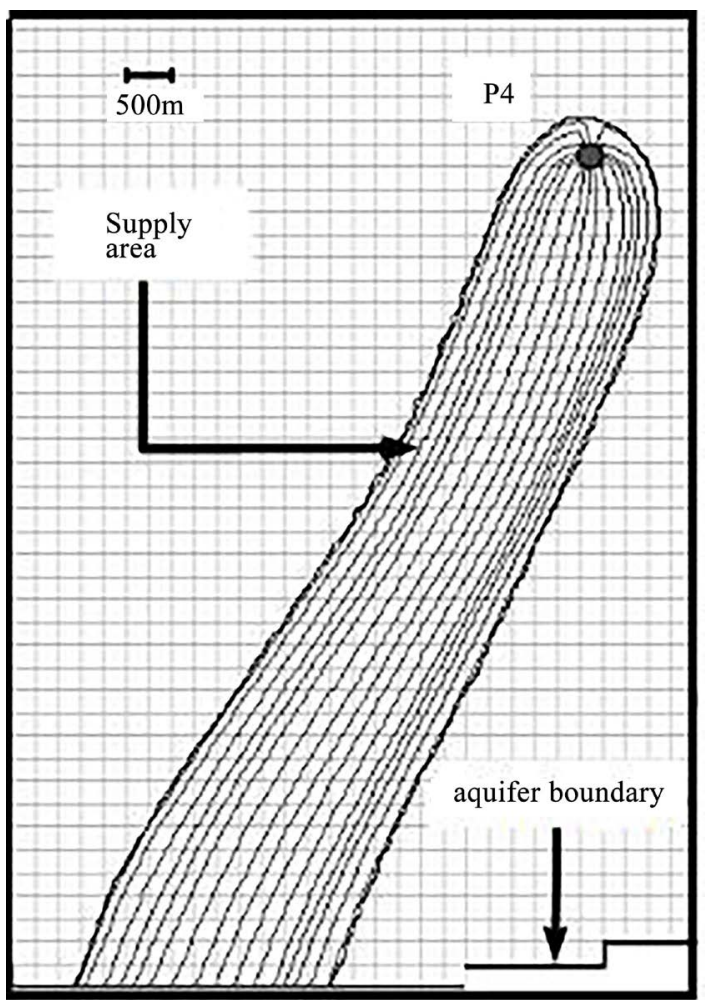

Figure 10. Enlarged view the feeding area of the borehole 1199/27 (P4). 


\section{Conclusions}

The inherent risks in the pollution of a groundwater resource depend on the activities on the soil surface. In order to preserve its quality over the years, delimitation around perimeter collection of the boreholes, within which potential sources of contamination are managed and controlled, is essential.

The delimitation of distant protection perimeters has shown that drinking water wells could be contaminated if the part of the southern water table, upstream of these wells, is polluted by persistent chemical substances. A warning belt consisting of control piezometers seems essential to periodically check the quality of the groundwater upstream of the boreholes in the southern part of the aquifer. It is also imperative to limit the establishment of potentially polluting industrial units outside the developed sites and to speed up the implementation of catchment protection perimeters.

\section{References}

[1] CSEC (Conseil Supérieur de l'Eau et du Climat) (2001) La Gestion de l'économie de l'eau et Recommandations. [The Economic Management of the Water and Recommendations.] 9e session, Agadir.

[2] Bzioui, M. (2000) Politique et stratégies de gestion des ressources en eau au Maroc. [Politics and Strategies of Water Resource Management in Morocco.] Académie du Royaume du Maroc. Session: La politique et la sécurité alimentaire du Maroc à l'aube du XXIe siècle, Rabat.

[3] CSE (Conseil Supérieur de l'Eau) (1992) L'économie de l'eau dans le secteur de l'irrigation. [The Economy of the Water in the Sector of the Irrigation.] 6e session, Agadir.

[4] Kholtei, S. (2002) Plaine de Berrechid; Caractérisations des eaux usées de Settat et de Berrechid; Evaluation de leurs impact sur la qualité des eaux souterraines et risque toxicologique. [Plain of Berrechid; Characterizations of Waste Water of Settat and Berrechid; Evaluation of their Impact on the Groundwater Quality and the Risk Toxicologique. Ph.D.] Doctorat d'Etat ès Sciences Physiques, Spécialité: Chimie Appliquée et environnement, Uni. Hassan II, Fac. Sc. Ben M'sik. Casablanca, 146 p.

[5] El Bouqdaoui, K. (2008) Contribution à la modélisation de l'écoulement et de la pollution par les nitrates en vue d'une meilleure gestion de la nappe de Berrechid (Maroc). [Contribution to the Modelling of the Flow and the Pollution by Nitrates with the Aim of a Better Management of the Groundwater of Berrechid (Morocco). Ph.D.] Doctorat National en Sciences de l'Environnement, Uni. Hassan II, Fac. Sc. Ain Chok Casablanca, 173 p.

[6] El Bouqdaoui, K., Aachib, M., Blaghen, M. and Kholtei, S. (2009) Modélisation de la pollution par les nitrates de la nappe de Berrechid (Maroc). [Modelling of the Pollution by Nitrates of the Groundwater of Berrechid (Morocco).] La Revue Internationale des Sciences et Technologie: Afrique Science, 5, 99-113.

[7] Agoussine, M. and Bouchaou, L. (2004) Les problèmes majeurs de la gestion des ressources en eau souterraines au Maroc. [The Major Problems of the Resource Management in Groundwater in Morocco.] Sécheresse, 2, 187-194.

[8] El Bouqdaoui, K., Aachib, M., Blaghen, M. and Kholtei, S. (2008) Modélisation de 
l'écoulement de la nappe de Berrechid (Maroc). [Modelling of the Flow of Groundwater of Berrechid (Morocco).] Revue Internationale de I Eau: La Houille Blanche, 2, 69-75. https://doi.org/10.1051/lhb:2008019

[9] ONEP (Office Nationale de l'Eau Potable) (1997) Etude de schéma directeur d'assainissement liquide de la ville de Berrechid. [Study of Master Plan of Purification Settles of Berrechid City.] Rapport final de la mission A.

[10] DGH (Direction Générale de l'Hydraulique) (Direction de la recherche et de la planification de l'eau) (1997) Etude de la plaine de Berrechid. [Study of the Plain of Berrechid] Mission 1, Description et analyse, Edition définitive (Annexes A et B).

[11] DGH (1985) Etude du plan directeur intégré d'aménagement des eaux des bassins sebou, Bougerag, et Oum errabia. [Study of the Main Plan Integrated by Arrangement of Waters of Ponds Sebou, Bougerag, and Oum Errabia.] Sous mission IB3-IB4, Etude hydrogéologique de la nappe de Berrechid.

[12] Bolelli, E. and Lesguise, N. (1951) Etude hydrogéologique de la région de Bouskoura-Mediouna-Berrechid. [Hydrogeologic Study of the Region of Bouskoura-Mediouna-Berrechid.] Rapport inéd., Centre Et. Hydrogéol., Rabat.

[13] Bolelli, E. and Lesguise, N. (1952) Chaouia. hydrogéologie du Maroc Monographie régionales. [Chaouia. Hydrogeology of Morocco. Regional Monograph] XIX Congres Géologique internationale d'Alger.

[14] Moullard, L. and Hazan, R. (1960) Nappe phréatique de la plaine de Berrechid. [Groundwater of the Plain of Berrechid.] Assoc. Inter. Hydrol. Sc. Helsinki, 52, 105-142.

[15] Moniton, L. and Nerat De Lesguise, M. (1960) Notice explicative de la carte hydrogéologique de la région de Casablanca. [Manual of the Hydrogeologic Card of the Region of Casablanca.] Notes et mémoires du service géologique, No. 131, Rabat, Maroc.

[16] Hazan, R. and Ferre, M. (1964) Notice hydrogéologique de la plaine de Berrechid. [Hydrogeologic Note of the Plain of Berrechid.] Services des ressources en eau, Rabat.

[17] El Mansouri, B. (1990) Modélisation mathématique des écoulements souterrains de la nappe de Berrechid, (Maroc). [Mathematical Modelling of the Subterranean Flows of the Tablecloth of Berrechid, (Morocco).] Rapport DEA, Univ. Sc. Tech. Lille I, 83 p.

[18] El Mansouri, B. (1993) Structure et modélisation quantitative de l'aquifère de Berrechid. Validation par l'approche géostatistique. [Structure and Quantitative Modelling of the Aquifer of Berrechid. Validation by the Approach Géostatistique. Ph.D.] Doctorat de l'université en géosciences, option: Hydrogéologie quantitative, $126 \mathrm{p}$.

[19] ABHBC (Agence du Bassin Hydraulique de Bouregreg et de la Chaouia) (2004) Synthèse des études antérieures et actualisation des données hydrogéologiques de la nappe de Berrechid. [Synthesis of the Previous Studies and the Updating of the Hydrogeologic Data of the Tablecloth of Berrechid.] Ministère de l'Aménagement du Territoire, de l'Eau et de l'Environnement (MATEE), $100 \mathrm{p}$.

[20] Gall, K. and Lamrhary, A. (1995) Manuel relatif à la délimitation des zones de protection de captage d'eaux souterraines. [Manuel Concerning the Demarcation of the Zones of Protection of Goundwaters.] Rapport, Office Nationale de l'Eau Potable, Rabat.

[21] Environmental Modeling Research Laboratory (1999) Groundwater Modeling Sys- 
tem-GMS Reference Manual. Birmingham Young University, Birmingham.

[22] Rasmussen, H. and Rouleau, A. (2003) Guide de détermination d'aires d'alimentation et de protection de captages d'eau souterraine. [Guide of Determination of Areas of Supply and Protection of Groundwater Catchment.] Centre d'études sur les ressources minérales Université de Québec à Chicoutimi, 182 p.

[23] Paradis, D. (2000) Comparaison de méthodes de détermination des périmètres de protection des ouvrages de captages d'eau souterraine dans les aquifères granulaires du piémont laurentien. [Comparison of Methods of Determination of the Perimeters of Protection of Groundwater catchment in the Granular Aquifers of Piedmont Laurentien.] Mémoire de maîtrise, Université du Quebec, INRS-Géoressources, 138 p.

[24] Bear, J. and Cheng, A.H.-D. (2016) Modeling Groundwater Flow and Contaminant Transport. Theory and Applications of Transport in Porous Media. Springer, Berlin, $834 \mathrm{p}$. 